"Environmental Considerations in a New Multilateral Agricultural Negotiation, and Associated Developing Country Implications"

John Whalley

CSGR Working Paper No. 46/99

November 1999
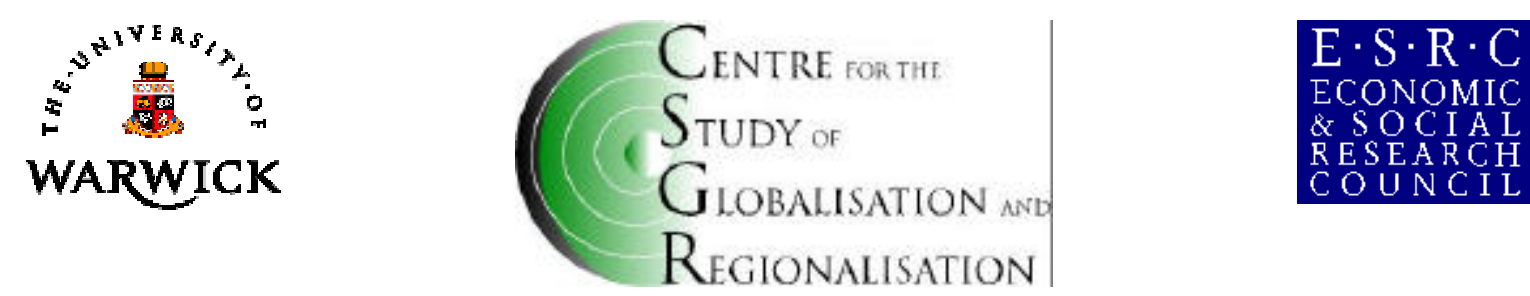

Centre for the Study of Globalisation and Regionalisation (CSGR), University of Warwick, Coventry CV4 7AL, United-Kingdom. URL: http://www.csgr.org 


\title{
Environmental Considerations in a New Multilateral Agricultural Negotiation, and Associated Developing Country Implications
}

John Whalley ${ }^{1}$

CSGR, University of Warwick and University of Western Ontario,

CSGR Working Paper No. 46/99

November 1999

\begin{abstract}
:
This paper discusses the potential role for environmental considerations in agricultural negotiations in the next WTO trade round, from developing country perspective. For now, as a non-trade issue in the new negotiations, environmental considerations are not the dominant concern, which is food security; although conflicts have arisen over the issue of multi functionality (agriculture serving multiple purposes including providing support for the rural environment), whether export subsidies have any rationale on environmental grounds, and the environmental case for the elimination of fishing subsidies. If new agricultural disciplines remain focused on the Uruguay Round issues of tightening the existing structure of bound tariffs, and limitations on domestic supports and export subsidies, then environmental concerns could enter in all of these. I suggest that for the developing countries, available studies seemingly point to substantial gains for them from internalization of externalities related to their own rural/agricultural activities and seemingly, further, environmental concerns should dominate trade concerns. However, the agriculture disciplines from the Uruguay Round seemingly provide relatively inefficient instruments to achieve substantive internalization of their externalities. Also, allowing environmental concerns to enter runs the risk of market restricting justifications (multi functionality) adversely affecting their export access to foreign markets. Finally, among the list of items on the trade and environmental agenda (Art 20 exceptions, MEAs, lax standards, eco-labeling) few or none can be addressed adequately as part of an environmental negotiation, and so environment in an agricultural negotiation is no substitute for a wider trade and environment negotiation. The bottom line is to suggest that developing countries focus heavily on environmental issues, perhaps even more so than trade, but that a WTO negotiation on agriculture is not the best forum to seek a remedy.
\end{abstract}

Keywords: Environment, Agriculture, Developing Countries.

Address for correspondence:

Prof. John Whalley

CSGR,

University of Warwick

Coventry CV4 7AL, UK

Email: J.Whalley@warwick.ac.uk

\footnotetext{
${ }^{1}$ This is a paper prepared for a World Bank conference on Agricultural Liberalization in the New Trade Round to be held in Geneva October 1 and 2. It draws on ongoing work on a MacArthur Foundation supported project on a possible World Environmental Organization. I am grateful to Pam Cooper, Kim Gertel, Raghav Jha, Peter Newell, Diana Tussie and Ben Zissimos for discussions on which the paper draws.
} 


\section{INTRODUCTION AND BACKGROUND}

This paper asks what potential there is for environmental considerations to enter an agricultural negotiation in a new WTO Round, and how could the developing countries ${ }^{2}$ be affected. The contention is that this is almost certain to happen in the key non-environmental negotiating areas of agriculture, services, and tariffs; and pressures will grow if the content of a separate trade and environment negotiation is downplayed relative to NGO expectations, as currently seems possible. $^{3}$

I begin from the assumption that a future negotiation in agriculture is likely to focus on achieving more substantive international disciplines using the structures of restraint on trade distorting agricultural policies that resulted in the Uruguay Round; further reducing tariffs (and possibly increasing tariff quotas), achieving deeper reductions in aggregate measures of support, and further cuts in export subsidies. ${ }^{4}$ Formally, there is little room for the wide ranging environmental considerations debated as part of the larger trade and environment issue to enter this structure; perhaps, save to a limited degree in SPS, and there presumably in an elaboration of

\footnotetext{
${ }^{2}$ The developing countries are, of course, a heterogenous group of countries with different interests in both agricultural trade and environmental matters; agricultural exporters, net food importers, high forest cover countries and high population density countries, to name but four.
}

${ }^{3}$ Both the Uruguay Round decisions of 1994 and the charter of the World Trade Organization (WTO) have been repeatedly characterized by environmental NGO's as lacking environmental content. It is said that the word environment hardly appears in approximately 24,000 pages of text and schedules, and that the drafting of the charter of the WTO represented the best chance for a generation to deal, in some fundamental way, with the role that environmental considerations can play in the post Uruguay Round trading system. Combined with the growing profile of trade and environment conflicts following the 1991 US-Mexico tuna-dolphin GATT panel report, pressure has been there for several years from environmental groups to deal centrally with the trade and environment issue in any new trade round. This was reflected in the recent WTO high level symposium (HLS) of March 1999 which devoted half of its discussion time to trade and environment issues (see the summary of the proceedings of the HLS by the International Institute for Sustainable Development (IISD (1999))). In the HLS, how a separate agricultural negotiation might deal with the environment was seemingly not a central focus of discussion; although Japan argued that trade rules need to take into account environmental benefits from local production, while New Zealand contested the claim that there were any environmental benefits from domestic subsidies, and Argentina argued that trade distorting production subsidies in environmental champion countries should be removed.

${ }^{4}$ This echoes Tangerman's (1997) approach to the agricultural content of a new Round. Although more recently Swinback (1999) has suggested the focus is likely to be heaviest on export subsidies. This is because, as Swinback argues, this is the most binding portion of the Uruguay Round agreements on EU agricultural policies, and calls are likely to come from elsewhere to eliminate entirely export subsidies on agricultural products rather than merely cut them. APEC trade ministers have recently made such a call (see Financial Times, September $11^{\text {th }}, 1999$ ). 
the risk assessment criteria. ${ }^{5}$ But the potential for environmental concerns to enter as non trade concerns through the detail of the negotiation seems clear, even though for now non-trade concerns relate more to food security issues than the environment.

The environmental content (outside of SPS) of the Uruguay Round agricultural negotiations was effectively limited to allowing Green Box coverage of payments made to farmers where payment was linked to provision of an environmental benefit. Countries have scheduled and notified programmes under these provisions, although for now (to my knowledge) there has not been any systematic assessment of how large or significant they are. The continuation of these arrangements seems likely in any new agreement.

Beyond this, the environmental-agriculture negotiating agenda seems likely to focus on a number of key issues. The first is multi functionality; the claim that agricultural production serves a wider purpose of protecting and promoting rural communities, the rural ecosystem, and meets generalized existence value. As such, trade protection in agriculture on environmental grounds may be justifiable. This is effectively the position advanced by Norway in their recent submission to the CTE (WTO (1999a)). The second is links between export subsidies in agriculture and the environment. A recent submission by 14 larger agricultural exporting countries claims there are no environmental links in the case of export subsidies, presumably with the intent of counteracting the multi functionality argument if and when later firm proposals to eliminate agricultural export subsidies emerge. Argentina, in a separate submission has warned against what they term environmental champion countries using environmental arguments as a way of defending production subsidies which distort trade. A third is in fisheries, where the argument that production subsidies exacerbate open access externality problems has been made to support proposals to reduce or eliminate such subsidies.

\footnotetext{
${ }^{5}$ See WTO (1998a). Also, I will for most of this paper treat SPS and TBT issues as involving standards, rather than as formal trade and environment issues, even though it is on occasion cast in that light(as in the EU-US beef hormones dispute).
} 
Beyond these, there are for now less clearly defined possibilities for environmental considerations to enter new negotiation on the other parts of the agricultural decisions from the Uruguay Round. Possibilities involve special credits for tariff cuts yielding environmental benefits, and penalties where harm occurs; and the introduction of environmental considerations into tariff quota schemes.

In thinking through the developing country implications of all this, I begin with a general discussion of trade and environment linkage in the agricultural area, focusing on the situation in developing countries. I suggest that a central problem in the whole area is that in concrete terms how these links operate are unclear, and current research provides relatively little to guide negotiators either quantitatively or qualitatively. An exhaustive categorization of uninternalized externalities associated with agricultural activities (in either developed or developing countries) does not, to my knowledge at least, exist. Many of the externalities involved are subtle and involve limited geographical areas (such as with water resources). Whether or not the effects of a particular externality are intensified or alleviated through more liberal trade is also often unclear, particularly as the changes induced by trade involve the whole economy (production in one sector expands and falls in another one, or production expands in one country and falls elsewhere).

Despite these ambiguities I nonetheless suggest that current literature for now seems to point to the conclusion that the social costs of uninternalized externalities associated with rural activities in developing countries substantially outweigh the potential gains to these countries from more liberal agricultural trade regimes; although there are extremely wide ranges to estimates and the studies are at best preliminary. This seemingly suggests that from a developing country viewpoint environmental considerations should enter agricultural trade negotiations with high weight, and that environmental considerations should even dominate trade considerations. 
But what needs setting against this line of argument is the feature that other instruments are usually available for internalizing the externalities at issue; and to the extent this is the case, then environmental considerations should receive less weight in the negotiations. Moreover, environmental considerations can potentially act in this area to restrict export market access for developing countries (the multi functionality debate).

A final point of importance to the developing countries is that were the above environmental adaptations of agricultural disciplines to arise in negotiation they would seemingly provide little opportunity for the core agenda items foreseen for a separate trade and environmental negotiation to be dealt with substantively. This might weaken developing country concerns, insofar as they have opposed such a negotiation, or might leave them fearful of the precedents involved. These broader issues would include country rights to use trade restricting measures on environmental grounds, use of trade measures in Multilateral Environmental Agreements (MEAs), lax environmental standards and their impact on trade, and eco-labeling. ${ }^{6}$ Thus an agricultural negotiation with environmental content will, in my view, remain at some distance from a full trade and environment negotiation. Whether or not to allow trade and environment to be a central negotiating agenda item in this form for the next Round has been prominent during the runup to the Seattle Ministerial in November/December 1999, and an option resisted by a number of developing countries who fear a slowing of their growth and development if they are subjected to externally (trade) enforced environmental restraint. ${ }^{7}$

The bottom line of the paper is thus to suggest that the benefits from internalizing uninternalized rural/agricultural externalities for the developing countries are probably large and larger than their trade benefits from an agricultural negotiation. But using an agricultural negotiation for the

\footnotetext{
${ }^{6}$ In the recent HLS, Canada supported by the US and Finland argued that environmental considerations need to figure prominently in upcoming WTO negotiations, citing as key issues; clarifying the relationship between multilateral environmental agreements (MEAs) and WTO rules through an interpretive statement; ensuring that ecolabels avoid disguised trade restrictions; promotion of the WTO Committee on Trade and Environment's (CTEs) work; and exploring a possible environmental review of WTO negotiations. See the summary in IISD (1999).

${ }^{7}$ Angola and Jamaica, among others, expressed these opinions in the HLS.
} 
purpose of internalizing these externalities will likely only yield benefits which are marginal at best relative to the underlying environmental problems. In many cases alternative and almost certainly superior environmental policy instruments exist. Also, the trade and environment agenda is larger and well beyond what an agricultural negotiation can deal with, either giving developing countries opposed to such a negotiation comfort or making them fearful of precedents. The conclusion I reach is that, environmental policy in developing countries would seem to merit a high weighting relative to trade policy, but using an agricultural trade negotiation as the instrument for pursuit of this objective seems to be questionable. These considerations, however, may not be sufficient to counteract pressures from other quarters to inject environmental considerations centrally into such a negotiation. 


\section{LINKS BETWEEN AGRICULTURAL TRADE LIBERALIZATION AND ENVIRONMENTAL CONSIDERATIONS}

\section{Agricultural Liberalization}

Agricultural trade liberalization in WTO discussion is now equated with the structure of disciplines over the use of trade distorting agricultural practices by national governments that emerged from the Uruguay Round. The need for such liberalization reflects the fact that as a sector agriculture remained to a large degree free of internationally negotiated disciplines from 1947 on, when the GATT was negotiated, until the Uruguay Round was concluded in 1994. The history is well known. ${ }^{8}$ Articles 11 and 16 of GATT as agreed in 1947 allowed for the use both of quota based import restrictions to support farm incomes, and of export subsidies. The 1955 open ended waiver granted to the United States effectively allowed them to use any form of trade restricting measures in agriculture. The terms of the1956 Accession for Switzerland (similar to the US waiver) and the 1957 EC Treaty of Rome with the Common Agricultural Policy and variable levies, both further contributed to internationally undisciplined agricultural trade interventions.

Agriculture was left in the late 1950's as (effectively) an undisciplined sector in which domestic programmes distorted production, and hence trade; and one in which autarky was more nearly approached than in any other major sector. This lack of discipline allowed distortions of world trade to grow, especially in budget terms, countries moved from net importer to net exporter status in key product areas, and export subsidy competition between exporters intensified. In the limited trade that occurred export subsidization became evermore a major factor. Attempts to place some form of discipline over these practices in the Kennedy and Tokyo Rounds to all intents and purposes failed, despite declarations of intent at the launch of each Round. The Uruguay Round, driven by access concerns of agricultural exporters, budget concerns over the cost of domestic support programmes, and fears of (eventually) unbridled competition among export subsidizers sought, for the first time, to inject international discipline into this sector.

\footnotetext{
${ }^{8}$ See Hathaway (1987), and Jackson (1989).
} 
The route taken was not to unwind all previously agreed departures from GATT/WTO principles, but instead to develop a new structure of restraints which would encase all these provisions and could then later be progressively tightened to achieve ever more substantive trade liberalization. The agreement that resulted was that all existing trade interventions were to be tariffied, and the resulting tariff rates bound; disbursements under domestic support programmes were to be capped and lowered, as were expenditures on export subsidies (see Ingersant, Rayner, and Hine (1995)).

As I note above, environmental considerations entered little into these decisions. The main component was that in the definition of the Green Box exceptions which covers support programmes to farmers not linked to output (decoupled), and which are not included in the aggregate measure of support. The Green Box exception explicitly allow for payments made to farmers which provide environmental benefits in the form of positive external effects. In drawing up schedules of programmes and in notifying the WTO which programmes are claimed as included in the Green Box these provisions have been used (primarily (and maybe exclusively) by OECD countries), but for now (to my knowledge) there is no systematic analysis of how large or important they are.

With this structure in place the next WTO agricultural negotiation will likely have as its main focus building on the Uruguay Round decisions in these three key areas (tariffs, domestic supports, export subsidies). The Uruguay Round mandates new agricultural negotiations to begin by 1999; making agriculture a key part of the so-called built in agenda driving the new Round. The emphasis in the Round seems likely to be on a focused, shorter Round (3 years), and given the scope of the Uruguay Round decisions in agriculture, the emphasis more likely to be on consolidating and enlarging them, than on adopting some new approach. 
Tangerman (1997), for instance, highlighted what he saw as the need to squeeze as much water as possible out of the Uruguay Round commitments in the 3 areas of agreement, more so than necessarily going further with deeper disciplines. Swinback (1999) suggests that the major focus will be on export subsidies, since there are the most binding portion of the disciplines on the EU, and several countries have indicated their wish to fully eliminate export subsidies in agriculture. ${ }^{9}$ For the purposes of the discussion here, I will take the term agricultural trade liberalization in a future trade Round to refer to further multilaterally based WTO liberalization within this structure, and focused on tariffication, bindings and transparency, and budget limitations on domestic supports and export subsidies. I will then discuss how environmental considerations could fit into each of these sub areas and what the implications are for the developing countries. ${ }^{10}$

\section{Environmental Objectives in Agricultural Trade Liberalization}

The interface of agricultural trade liberalization with environmental issues is complex, and defining environmental objectives in agricultural trade liberalization requires a little background discussion. From an economists point of view, the role for environmental objectives in trade negotiations fundamentally comes down to whether or not various forms of trade intervention (or restrictions on trade interventions) intensify or worsen the effects of various uninternalized environmental externalities (see Uimonen and Whalley (1997)). Precisely what these externalities are, and the ways in which more open trade can intensify or weaken their effects is, however, often not clear from the literature.

\footnotetext{
${ }^{9}$ Swinback (1999) also identifies the diverse interests and regions in a new negotiation within countries. In the EU, for instance, protection for high-cost butter and sugar relies on special safeguard provisions in the 1994 WTO Agreement; and these would disappear were the agreement were not to be extended. A recent statement by APEC trade ministers on a new trade round explicitly calls for export subsidies in agriculture to be eliminated (Financial Times, September 11, 1999).

${ }^{10}$ There are a number of other environmental issues that could surface, in an agricultural negotiation, including those involved with the Sanitary and Phyto Sanitary Agreement, and technical barriers to trade (see Uimonen and Whalley (1997) and Uimonen (1998)). A major point of conflict in this area has been the beef hormones dispute between the US and the EU. This is a standards issue, so much as a trade and environment issue, but sometimes gets included in the latter. Other possible issues include special rules for dispute settlement cases with environmental content, and whether pre or post Round environmental impact assessments should be made. I do not touch on these here to keep the paper focused on what seem to me to be the key issues linking environmental concerns and an agricultural negotiation.
} 
Externalities arise where the actions of one agent affect other agents, and these interactions are not taken into account when the first agent formulates their best course of action. Thus, chemical plants which emit particles which make the laundry outside the plant difficult to operate are a classic case of an externality; since the owner/operator of the plant does not take into account the added costs inflicted on the laundry when deciding the output of the chemical plant. Pigou (1918) was the economist who first noted the difference between marginal private and marginal social cost that externalities create in such circumstances, and emphasized the need to correct (or internalize) externalities through a (Pigouvian) tax. ${ }^{11}$ A later key contribution to the theory of externalities by Coase (1960) stressed that externalities were reciprocal, and that some prior allocation of property rights was required before Pigouvian tax liabilities could be assigned. Coase saw property rights allocation as essentially affecting issues of income distribution. He also suggested that deals negotiated between parties to an externality prior to the use of an internalization instrument could make such an instrument unnecessary, and even counter productive.

Environmental externalities are a subset of a wider class of externalities some of which are nonenvironmental. ${ }^{12}$ External effects can also be either beneficial or harmful. The dominant externalities that economists study though (degradation, crowding, waste, noise) are thought of environmental, and most are also thought of as harmful (though this is not always the case). These externalities can also be geographically limited in impact (pesticide use by one farmer affects neighbouring plots through leeching), cross border (acid rain depositions, water use by upstream countries affecting water availability downstream), or even global (carbon emissions, ozone/CFCs). They can be manifested in physical form, as in the examples above, or can have cross border impacts via so called existence value (OECD residents value the existence of flora and fauna in the rainforest). All have the same underlying structure; actions of one group of

\footnotetext{
${ }^{11}$ See also Meade's (1952) important classification of externalities as consumption-consumption, consumptionproduction, and production-production.

${ }^{12}$ My educational attainment raising the probability that misdirected mail sent to me will be appropriately rerouted is an example of a non-environmental externality.
} 
agents affect in some way another group, and these impacts are not directly taken into account in the economic actions of the first group.

From the point of view of agricultural trade negotiations, the issue is whether the design of trade measures should take into account agricultural environmental externalities, even though on conventional trade grounds most trade measures are thought of as distorting, and hence undesirable. Central is the issue of whether freer trade will intensify harmful effects of environmental externalities, and if so, whether moves towards freer trade should be restricted.

The agreement in the literature seems to be that the best way to internalize an externality is through a Pigouvian tax on production once property rights are assigned, not a tax on trade which affects both production and consumption (see Anderson (1992b), and Uimonen and Whalley (1997)). However, with a cross border externality, residents of the source country may well be unwilling to internalize the externality through a first best instrument and especially so where the damage falls wholly outside the jurisdiction which is the source of the externality. This applies to existence value related external effects, as well as those with physical form. In such cases, the issue is whether the use of a second best trade instrument is better than using no instrument at all. The literature, perhaps not surprisingly, comes to the conclusion that the outcome is ambiguous. A second best instrument may or may not be better than no instrument at all; an application of what economists call the theory of the second best. ${ }^{13}$

Trade and environment debates involving WTO issues have focused on a range of issues, which it has been assumed would make up the core of an eventual trade and environment negotiation. These include whether or not countries should be able to use trade restricting measures for environmental purposes (the Tuna-Dolphin dispute), the use of trade sanctions to enforce multilateral environmental agreements in the presence of free riding (such as with the Montreal Protocol), whether lax environmental standards abroad should be counteravailable via duties,

\footnotetext{
${ }^{13}$ See Lipsey and Lancaster (1957).
} 
whether export subsidies for pollution control equipment should be allowed, whether pre existing trade agreements should be allowed to constrain environmental agreements, whether trade negotiations themselves tend to lower environmental standards, the trade implications of ecolabelling, and other matters. Not all of these are externality related issues as economists usually think of them. Lax standards, for instance, are posed as a competitiveness issue; and one of unfairness of trade, comparable to conventional dumping and subsidization; areas where economists generally have little sympathy for the use of trade restrictions.

\section{The Dimensions of Agricultural/Environmental Linkage}

Key to evaluating how environmental considerations could enter an agricultural trade negotiation is an assessment of both how far reaching and how quantitatively important the elements of linkage actually are that could potentially arise. In Table 1, I have tried to itemize what some of the more significant agriculturally based environmental externalities are, whose linkage to domestic programmes of various kinds might be raised in an agricultural negotiation.

I begin with existence value issues related to rural/agricultural activity. In recent WTO discussion, this has taken on the term "multi functionality". This issue was raised by Norway in their submission to the WTO Committee on Trade and the Environment (see WTO (1999a)). In their words "......the agricultural landscape is the most obvious environmental benefit or public good produced jointly with agricultural production. Arable land amounts to only $3 \%$ of the total land area of Norway; because of this scarcity, extensive measures have been necessary to ensure its protection; including both general policies and specific measures.

.......agricultural contributes to the conservation of biological diversity. In Norway, the agricultural landscape is the only habitat of around $10-20 \%$ of the threatened species. Conserving biodiversity is therefore closely related to protection of the agricultural landscape. Moreover, increased trade in agricultural products increases the risk of alien species being introduced. 
agriculture in Norway contributes to good phytosanitary, zoosanitary, and public health. Under considerably increased trade, control measures may not fully offset the increased risk related to the introduction of contagious substances and diseases."

Many considerations thus enter into existence (or use) value, including some not mentioned in the Norwegian submission, such as the wider societal identification with the family farm as a key part of national culture. The argument is that if trade liberalization reduces the size of the agricultural sector, existence or use values which are not accounted for in the private decisions of individual farmers will be adversely impacted. The externality is reflected in the existence value to those outside the farm community, and the claim is that agricultural trade liberalization that reduces production in protected or high support countries potentially adversely impacts on existence value in those countries. 
$\underline{\text { Table } 1}$

\section{Environmental Externalities Potentially Impacted by Agricultural Trade Negotiations}

\section{Generalized existence value for agricultural/rural activity within countries}

Existence value over rural community activity within countries. Freer trade in agriculture induces specialization, and in some countries smaller rural communities.

\section{Generalized existence value across countries for country specific resources affected by agricultural activity}

Existence value for forests and biodiversity is affected by changed agricultural patterns (land clearing) in countries either exporting agricultural products or increasing production for home markets. This is a major area of concern for OECD based NGO's.

\section{Soil Erosion}

Depositions of soil into neighbouring plots (with silting of hydro dams in countries with hilly terrain) due to water run off or windborne erosion. Severity increases in low income or desertified countries. Erosion in importing countries may worsen or improve with trade liberalization depending upon whether the crop involved is more or less erosive; the erosion situation can also improve in importing but worsen in exporting countries.

\section{Fertilizer/Pesticide Use}

Leeching onto neighbouring plots associated with heavy use of fertilizers and/or pesticides. Many developing countries have significant fertilizer subsidies which exacerbate such effects. Trade liberalization that allows more imports and reduces domestic production of crops with these production characteristics may weaken the severity of such environmental externalities.

\section{Open Access Resources}

Over exploitation of resources due to ill defined property rights. Examples include fisheries, shared aquifers and water tables, forests and the collecting of firewood. Increased exports of fish from a local fishery can thus be environmentally worsening, as can increased catches for the home market occurring behind a protective trade barrier.

\section{Waste and Degradation from Selected Agricultural Practices}

Some environmental practices generate waste and degradation not internalized in individual farmers calculations. These include smoke and haze from fire based land clearing (Indonesia, at present), soil contamination from such practices as rearing shrimp in paddy (now banned in Thailand). Liberalization that increases production associated with these practices can worsen the environmental situation. 


\section{Water Resource Allocation}

Water allocation practices in various localities encounter a range of externality related problems, stemming from common access to water sources (water table levels in the North China plane), an inability to price and monitor the use of irrigated water, the lack of adequate metering, and other factors. These problems may also intensify or weaken under agricultural trade liberalization.

\section{Global Environmental Considerations}

Methane emissions related to paddy production, impacts on carbon sinks (forests) from changed land use, and carbon emissions from standing herds (cattle) are an element (though not the dominant element) in discussions of global warming and climate change. Agricultural liberalization that increases production globally may be seen as intensifying these global externalities.

Beyond existence value considerations within economies, there are also existence value issues across countries. These relate, in the main, to deforestation and loss of biodiversity in developing countries, both of which are widely thought to occur as the agricultural sector expands and land clearing accelerates. Such existence value considerations have been a major theme emphasized by developed country NGO groups in the wider trade and environment debate. ${ }^{14}$ Also, countries who are the custodians of specific environmental assets (such as forests) fear that trade measures used against them in name of environmental conservation (bans on imports of tropical lumber, for instance) and that these will impair their growth and development, further inflaming potential conflicts over this dimension of linkage between developed and developing countries.

Soil erosion arises from a variety of causes, although one has also to differentiate between onsite and offsite effects . A key one is population growth which results in progressive division of plot size, with ever more spillover of topsoil into neighbouring plots, river estuaries, hydro dams, and, in the case of more heavily desert countries, wind borne soil loss. Soil erosion reduces

\footnotetext{
${ }^{14}$ The Norwegian submission to the CTE discusses the implications of a shift in agricultural production away from countries with high domestic supports to those with lower domestic supports as agricultural liberalization proceeds. It emphasizes that low support countries are generally also high biodiversity countries, and hence concludes such a shift of production could be detrimental on environmental grounds. See also the summary of NGO arguments on this point made to the HLS in IISD (1999).
} 
agricultural productivity, and in some cases agricultural land availability per capita. Soil erosion can also had the effect of reducing fodder available for cattle. Externality related soil quality problems arise from the leeching of fertilizers and pesticides to neighbouring plots, contaminating neighbours soil. The 1998 Human Development Report (UN (1999)) estimates that in Bakina Faso and Mali one person in six has been forced to leave their land as it has turned into desert; and that desertification based soil erosion has a world-wide annual cost of $\$ 42$ billion in lost income, $\$ 9$ billion of which arises in Africa.

A recent survey of studies of the cost of soil erosion in developing countries (Barbier (1995)) places the annual losses by country in a range from 1 to $15 \%$ of GDP. Knut et.al. (1996) in a study of Nicaragua estimated annual productivity losses due to soil erosion by crop as coffee $1.26 \%$, beans $2.52 \%$, maize $2.41 \%$, sorghum $1.35 \%$. Magrath and Arens (1989) in a study of soil erosion losses in Java in 1985, estimated annual losses of around 4\% of the value of crops harvested. Cruz, Francisco, and Conway (1988) examining two watersheds in the Philippines and focussing only on additional sedimentary costs for hydro power installation (reduced water storage capacity for hydro power, reductions in the service life of the dam, and reduced hydro power) estimated costs of $\$ 27 /$ hectare of agricultural land in the watershed, a significant portion of the value of crop yields per hectare.

In addition to soil erosion and soil quality, another key set of agriculture related externalities arise with common property resources; resources where the property rights are ill-defined and over exploitation of resources occurs. These include deforestation associated with land clearing, slash and burn cultivation, squatting, and, in some countries, the collection of firewood. These problems are especially severe in Africa, and Central and Latin America. For Ghana, one of the less severe cases, Lopez (1977) estimated that over cultivation of land at the expense of forests runs at $25 \%$ of land use. Over exploitation of fisheries is a further problem. Shared access to water through common aquifers and ground water resulting in reduced water tables, cause especially severe problem in the North China plain. 
Yet another category of environmentally based externalities related to agriculture arise from degradation effects which go beyond the immediate area of the agricultural activity. Smoke from fires initiated for forest clearing, and the health and safety effects which accompany such occurrences have become a major issue with the haze problems on Indonesian islands close to Singapore and Malaysia (see Glover and Jessup (1999)). Another concern has been soil degradation from practices such as shrimp farming in paddy fields in countries such as Thailand, where those engaging in such practices typically rent rather than own the land. In all such cases, the argument is that agricultural liberalization may increase production which has associated practices which worsen environmental quality.

Water resource allocation is another area where potentially significant agriculture related externalities arise, and whose severity can be also affected by agricultural trade liberalization. Such externalities can arise from the drilling of tube wells where water resources are shared; excess flooding where irrigated water washes land or sparse water supplies when dispensed through open irrigation channels; excess water use where metering is incomplete. Again, the concern is that if agricultural trade liberalization increases production and changes the crop pattern in countries with such externalities, their severity may grow.

Finally, there are global environmental externalities whose severity may be impacted by agricultural trade liberalization. These include climate change related external effects, such as methane emissions from paddy, reduced carbon sinks from land clearing driven deforestation, and carbon emissions from flatulent cattle. Other impacts include the loss of gene pools through forest and wildlife erosion, and mangrove losses due to shrimp farming and local fisheries management.

All of these are examples of agriculture related environmental externalities, and the issue is both the size and sign of their linkage to agricultural trade liberalization. Liberalization will intensify some of these external effects, and mute others. Liberalization will likely increase the volume of 
agricultural production, while also changing the composition of production and its location. The effects involved can be subtle. Movement may be from more erosive towards less erosive crops, or vice versa. It may be from localities with more intense environmental externalities to less intense, or also vice versa. Some of these effects will be across countries, but many will be within countries and across localities and production methods which differ in their externality implications. The net effects are unclear, and with limited amounts of conclusive research on them. ${ }^{15}$

\section{The Quantitative Dimensions of Environmental and Trade Considerations in Agriculture}

If these are examples of core environmental externalities that might enter an agricultural trade negotiation, how important are they and how do they compare to the trade concern to better harness gains from trade through more specialization in production? These questions unfortunately have no simple answer to them both because the analytics are missing, and there are inadequacies of data and studies. Moreover, the benchmark for comparison needs to be carefully specified.

At an analytical level, there has been little or no work that has been done on whether or not geographical concentration of harmful effects is a good or bad thing. With increased specialization of production which accompanies more liberal trade, there is a presumption that production will be more concentrated geographically. The question is whether this will be good or bad from a global point of view. If the damage functions (giving damage associated with levels of output in localities) are convex to the output axis, and assuming that damage remains in the locality, then total damage is reduced by having production concentrated in a smaller number of localities. If damage functions are concave to the output axis, then this situation would be reversed. Knowledge of the shape of the damage functions is thus critical for any results in this area.

\footnotetext{
${ }^{15}$ See the analysis of the impacts of tariff cuts for potatoes on soil erosion in Sri Lanka in Weerahewa (1999), where the outcome hinges on whether increased potato production is at the expense of more or less erosive other crops.
} 
Also, if the population density differs between countries but the harm is borne by all in the locality, then damage per capita may be similar but total damage will vary. A general presumption that moving externality causing production from high to low population countries from a global point of view seems to have merit; but such a directional change may be consistent with, or opposite to that implied by more liberal trade.

At a more empirical level, existing studies, for what they are worth, seem to point in the direction of the gains (particularly to developing countries) from achieving internalization of key agriculturally related externalities as substantially outweighing potential gains from the removal of trade related distortions of international trade. A recent paper jointly with Raghav Jha (Jha and Whalley (1999)) reviews what we call the environmental regime in a sample of developing countries for which there are studies of environmental costs, suggesting that annual gains from full internalization might be up to $10 \%$ of GDP per year. Of those, what we call degradation related externalities (soil erosion, deforestation, general land degradation, and open access problems) could account for $70-80 \%$ of the total.

Jha and Whalley rely heavily on cross country comparative studies of Asian countries undertaken for the Asian Development Bank, some of which are cited in Table 2. These ADB studies suggest that annual productivity losses due to soil erosion, deforestation and land degradation in 
Table 2

\section{Estimates of Environmental Costs in Selected Asian Countries due to the ADB and cited in Jha and Whalley (1999)}

\section{China}

- Productivity losses due to soil erosion, deforestation and land degradation, water shortages and destruction of wetlands in 1990 put at US\$ 13.9-26.6 billion annually or $3.8-7.3 \%$ of GDP

\section{India}

Total environmental costs of US\$ 13.8 billion in 1992, or 6\% of GDP; urban air pollution costs $\$ 1.3$ billion; health costs from water quality are $\$ 5.7$ billion; soil erosion costs are $\$ 2.4$ billion; deforestation costs are put at $\$ 214$ million. Traffic related costs, pollution costs from toxic wastes, biodiversity losses are excluded from the total.

\section{$\underline{\text { Pakistan }}$}

Health impacts of air and water pollution and productivity losses from deforestation and soil erosion put at US\$ 1.7 billion in the early 1990's; or 3.3\% of GDP

Sources: Agarwal (1996), ADB (1997), and UNHDR (1998) and cited in Jha and Whalley (1999). 
China, for instance, could be as large as 7\% of GDP for the early 1990's. If the health and productivity losses from pollution in cities are added (in the region of 1.7 to $2.5 \%$ of GDP), combined annual cost estimates from environmental damage are in the region of $10 \%$ of GDP. A further study of China by Smil (1992) (not included in Table 2 as it was not in ADB study) based on 1988 data puts losses due to environmental degradation (farmland loss, nutrient loss, flooding, timber loss) at around $10 \%$ of GDP, as against losses from pollutants of perhaps $2 \%$ of GDP. Estimates of the costs of damage from a series of environmental sources in India in 1992 are put at about $6 \%$ of GDP in the ADB studies. The elements included cover urban air pollution, health costs from water quality, soil erosion, and deforestation, while the study excludes traffic related costs, pollution costs from toxic wastes, and biodiversity losses. Studies for Pakistan show smaller but still sizeable effects.

In contrast, model based studies of the gains from agricultural liberalization performed at the time of the Uruguay Round generally produce much smaller estimates. These studies are largely numerical general equilibrium models in which production and consumption (preferences) structures are specified within countries, with trade by commodity by country given as the difference between the two. Market clearing prevails, and trade interventions change not only the pattern of trade but also consumption and production within regions. Models are benchmarked to a base year, and various counterfactual simulation experiments conducted reflecting the liberalization agreed to in the Uruguay Round. The papers by Francois, MacDonald and Nordström (1996); Harrison, Rutherford, and Tarr (1996); and Goldin and van der Mensbrugghe (1996) cited in Table 3 are among the prominent in this literature.

The agricultural liberalization analyzed in these models is generally the Uruguay Round package of tariff cuts, reductions in domestic supports and export subsidies, but there has been some discussion both of how much liberalization actually occurred in the Round, and whether the models incorporate more liberalization than that actually implemented. ${ }^{1}$ Thus, while not

\footnotetext{
${ }^{1}$ See Mingco's (1996) discussion of dirty tariffication, for instance.
} 
providing a wholly fair comparison to the estimates presented in Table 2, since less than full liberalization of agricultural trade is involved, a feature of Table 3 is the small the trade gains reported compared to the estimated gains from internalization of externalities in Table 2. China, for instance, has environmental gains of US\$13.9-26.6 billion (1990 prices) compared to an estimated gain of \$-0.8 to 0.27 billion from Uruguay Round agricultural liberalization.

In passing, it should also be noted that results from these studies tend to be inconsistent one with another, and so only provide a rough guide as to potential impacts. Compare, for instance, the HRT estimates for the EU and Japan to those of FNM. There are also changes of sign for the developing countries, although the effects involved are generally small.

Despite this, one way of possibly arguing on the basis of Tables 2 and 3 would be that agriculture related environmental policy should have a higher weighting in developing countries in overall policy making than agricultural trade policy; and hence to exclude environmental considerations from agricultural trade negotiations would be ill advised for such countries. The conclusion might seem to be that they should be full centre in deliberations in the Round.

This, however, is an overly simplistic view of the policy making judgement calls needed as far as environment in agricultural trade negotiations is concerned. This is because trade policy is a poor (and even ineffective) instrument to use for the conduct of environmental policy. The environmental externalities at issue reflect ill defined property rights, cumbersome practices of state owned entities (including irrigation), weak and ineffective legal systems, and these are ills best dealt with directly; not indirectly through constraints on an agricultural trade negotiation. How many of these externalities can be effectively remedied by special provisions in agricultural trade negotiations. Also, from a developing country point of view, externalities which involve cross border effects (such as cross country existence value) raise the possibility of truncated market access on environmental grounds, and preventing losses on this score is something not captured in the studies cited above. 
Thus, a broad sweep of the studies seems to suggest that environmental concerns are indeed important, and especially to the developing countries. But pursuing them through an agricultural trade negotiation seems an indirect and inefficient way to achieve internalization, and allowing for the possibility of new market closing measures against the developing countries suggests even further caution.

\section{$\underline{\text { Table } 3}$}

Model Based Estimates of the Gains from Agricultural Trade Liberalization in the Uruguay Round

HRT $^{2}$ (IRTS) (1992 \$bill)

China

Indonesia

India

Argentina

Brazil

EU (12)

US

Japan
$-0.8$

0.3

0.2

(South Asia)

0.7

0.1

26.4

3.2

16.8
FNM $^{3}$ (IRTS)

(1992 \$bill)

0.27

0.40

(East Asia)

$-0.21$

(South China)

1.03

(Latin America)
$\operatorname{GVdM}^{4}$ (CRS)

(\% of income in 2002)

$$
0.5 \%
$$

$$
0.0 \%
$$

(other Latin America)

\footnotetext{
${ }^{2}$ Harrison, Rutherford, and Tarr (1996), Table 8.7.

${ }^{3}$ Francois, McDonald, and Nordström (1996), Table 9.11, fixed capital stock case.

${ }^{4}$ Goldin and van der Mensbrugghe (1996) Table 6.5.
} 


\section{ENVIRONMENTAL CONSIDERATIONS IN AN AGRICULTURE TRADE NEGOTIATION AND THE DEVELOPING COUNTRY INTEREST}

By casting a future agricultural trade negotiation broadly as an attempt to tighten disciplines within each of the three categories of (tariffs, domestic supports, and export subsidies), the questions that naturally follow are how might environmental considerations enter into each of these, and what are the implications for the developing countries?

At a broad level, it is perhaps worth noting that an agricultural negotiation will almost certainly be seen largely for what it is, a negotiation on agricultural policies, not the environment. It is true that there has already been considerable discussion of non-trade issues in an agricultural negotiation in the run up to the November Seattle Ministerial meeting, but the key non-trade issue for now seems to be food security, not the environment. ${ }^{5}$ Environmental concerns seem more likely to enter the discussion centrally due to NGO pressure, especially if there is a perception in NGO circles that the trade and environment profile as a general issue could be lowered in the agenda setting process for a new Round. These are more likely to be driving factors for inclusion than the spontaneous enthusiasm for environmental linkage of agricultural negotiators. The argument that other instruments are available for dealing with environmental concerns will likely be repeatedly made, and will probably diffuse some of the pressure for making environmental concerns a central part of an agricultural negotiation. Pressures will, however, undoubtedly remain. Also, environmental arguments will be made to support trade positions; such as on the subsidy issue.

It is also likely to be the case that the enthusiasm for adding environmental concerns to the agricultural negotiating agenda may be especially muted in developing country circles.

Developing countries have generally viewed the trade and environment debate as something

\footnotetext{
${ }^{5}$ The submissions by Norway (WTO (1999a)) and Argentina (WTO (1998c)) seem to the two instances where environmental issues have been discussed centrally as non trade issues. Norway has emphasized what they see as the "multifunctional" nature of agriculture as a justification for agricultural subsidization; Argentina has warned over the protectionist nature of such subsidies, and the impact on poverty in exporting countries. See the discussion of these positions in ICTSD (1999) p.7.
} 
which could trigger new trade measures against them on environmental grounds, and one which would only seem to slow their growth and development. They were cautious on a general negotiation after the Uruguay Round concluded in 1994, opposed it before and during the 1996 Singapore WTO Ministerial meeting, and have largely remained so since. ${ }^{6}$ The precedent involved in allowing environment to enter an agricultural negotiation in a major way would be a concern, as would the potential emergence of access restricting measures justified on environmental grounds.

Environmental issues will also likely enter an agricultural negotiation in ways which differ from those thought of as shaping a more general trade and environment negotiation. General trade and environment issues such as rights of countries to restrict trade on environmental grounds will not be dealt with in centrally, nor would, say, the use of trade measures in multilateral environmental agreements. But since an agricultural negotiation would deal with both restraints on trade (tariffs and export subsidies) and domestic policies (production supports), the environmental content of debate would not only be about whether particular trade impacting agricultural measures should be treated differently under agricultural disciplines, it could also touch on whether particular domestic measures are needed for environmental management, and hence need to be free of any new disciplines. Domestic support programmes which are perceived to yield positive environmental externalities are an example (such as Integrated Pest Management programmes in countries such as Indonesia). ${ }^{7}$ Furthermore, WTO trade agreements could potentially discipline domestic measures with harmful external effects (such as fertilizer subsidies).

Given the above, it may be of interest to set out some possible scenarios as to how environment could both appear in and influence an agricultural component of a new Trade Round, and assess the potential implications for the developing countries.

\footnotetext{
${ }^{6}$ See Whalley (1996) for a discussion of the trade and environment issue beyond the 1996 Singapore WTO Ministerial.

${ }^{7}$ See Resosudarmo (1999).
} 
In Table 4 I have attempted to set out what some of these elements could be. I first suggest that there may be prolonged general debate on environment trade linkage as a likely component to an agricultural negotiation, even after it is launched. The relative absence of firm studies and data will likely mean that parties to the negotiation will be able to (or may wish to) repeatedly raise general concerns supported by specific experiences or views. The lack of any clear or general propositions in this area will likely mean that such debate is repeatedly inconclusive. Thus, for instance, the recent argument by 14 countries to the CTE that "no environmental benefits can be associated with the provision of export subsidies" seems too strong a claim to go without challenge. For instance, consider a country exporting two crops both of which cause soil erosion. Subsidization of exports of the less erosive crop could lead to reduced aggregate erosion. The point would seem to be that there are no general or overarching propositions in this area, and so the potential is for protracted debate. However, the potential that such debate would eventually legitimize some formal structure through which environmental concerns could enter the negotiation should, in my view, not be lightly dismissed.

I suggest multi functionality will fit as a debating issue into this general category. If existence value is accepted as conceptually sound, and it is widely used in environmental economics, it is an argument that will not go away. Agricultural exporters will argue that it is simply a mechanism to legitimize protection, and the main objective is protection and avoidance of the domestic political consequences of liberalization. They might be right, but in the absence of further study, typically through willingness to pay type studies or the use of other valuation techniques, we will not know.

The second level at which I see environmental considerations entering an agricultural negotiation is within the three agricultural negotiating areas defined by the Uruguay Round decisions. As already noted, the Green Box provisions from the Uruguay Round allow for payments to farmers which cover the delivery of environmental benefits. The expectation seems to be that this structure will remain, but attempts to more clearly delineate what precisely these benefits are 
may be made. If, as some expect, major focus in the negotiations turns on export subsidies; the issue of whether or not environmental benefits can justify export subsidies could become high profile.

Where environmental benefits (costs) are deemed to accompany the use of particular instruments or programmes, pressures to preferentially (more harshly) treat them under any new disciplines could also emerge. These could include tariff arrangements, tariff quotas, inclusion in AMS calculative, and export subsidy disciplines. Here, there would be several difficult issues to resolve as part of the negotiation. How are benefits (or damage) to be defined and measured? Should benefits (for damage) be calculated globally (ie. taking both importing and exporting countries into account simultaneously), or does harm (or benefit) in either an importing or exporting country justify a departure from agreed disciplines? How do benefits or damage calculations take into account resource reallocations throughout the economy as behaviour responds to external effects? 


\section{Table 4}

\section{A Scenario for Environmental Debate in an Agricultural Trade Negotiation}

\section{A. General Debate on Environment-Agricultural Trade Linkages}

- What are the ways in which the environment is either adversely affected or harmed by agricultural trade liberalization?

- $\quad$ Multi functionality; the multiple roles played by the agricultural sector, including in supporting rural activities; existence value.

- Do export subsidies have any environmental justification?

B. Possible Discussion of Environmental Considerations in each of the Instrument Areas from Further Uruguay Round Decisions

- $\quad$ Further elaboration on Green Box rules on programmes delivering environmental benefits

- $\quad$ Exceptions from tariff cuts on environmental grounds

- $\quad$ Extra credit for tariff cuts where environmental benefits result

- $\quad$ Programme expenditures to be removed from AMS calculations on the grounds that environmental benefits result

- Use of tariff quota design for environmental purposes

- $\quad$ Programme expenditures to be counted more harshly where there are adverse environmental effects

- $\quad$ Export subsidies with positive environmental effects to be removed (or treated less severely) in export subsidy restraints. Reverse where adverse environmental effects apply

C. Areas of Wider Trade and Environment Debate Not Likely To Be Treated in an Agricultural Trade Negotiation

- $\quad$ Rights of countries to use trade restricting measures on environmental grounds

- Multilateral Environment Agreements, and their use of trade measures

- Lax environmental standards/subsidization

- $\quad$ Eco-labelling 
Thirdly, and as Table 4 reports, a feature of such a scenario is that most of the key issues which have already arisen in the trade and environment debate will remain untouched by an agricultural negotiation, since nothing in the structure of an agricultural negotiation permits them to be discussed. This includes rights of countries to use trade restricting measures on environmental grounds, the relationship between multilateral environmental agreements and trade measures, lax environmental agreements and subsidization, and eco-labelling. Thus, a key feature of an agricultural negotiation is that as a way of dealing with trade and environment issues more generally and in ways advocates would propose, an agricultural negotiation will at the end of the day likely prove an unsatisfactory vehicle.

Where does this all leave the developing countries? First, the quantitative implications of much of this discussion for their own environmental situation seem small, even though their own gains from internalization seem so large. Developing countries would seem well advised to pursue their own environmental policy agenda elsewhere, and primarily through domestic policy, rather than through an agricultural negotiation. Second, the potential is there for market restricting measures to emerge which are justified by appeal to environmental arguments and which harm developing country export performance. This would suggest further caution on the developing country side. Third, there is the seeming weak relationship between the environmental content of an agricultural negotiation relative to what would seem to be the agenda for a broader trade and environment negotiation. This may give developing countries opposed to such a broader negotiation grounds for taking a more relaxed attitude to the issue, or in turn may intensify concerns in that while only weakly linked the precedents involved could be damaging.

The bottom line seems to be that while acknowledging that environmental problems in the developing world are of large proportions, an agricultural negotiation in the WTO will not be the place for them to solve these problems. Other remedies will likely dominate. Equally, the potential exists for adverse effects, including the maintenance of agricultural trade restrictions against them justified on environmental grounds. 


\section{CONCLUSION}

This paper discusses both how environmental considerations could enter an agricultural negotiation in a new WTO trade Round and how this might affect the developing countries. It assumes that an agricultural negotiation would focus on tightening existing discipline in each of the three instrument categories set out in the Uruguay Round negotiations; tariffs, domestic supports, export subsidies. It also presumes that the dominant environmental considerations would reflect uninternalized environmental externalities originating from agricultural/rural activities.

It argues the following points

1. Existing studies (of which there seem to be relatively few) seem to suggest that the gains from internalization of major agricultural-related externalities in developing countries are large relative to the gains to them from lowered agricultural trade barriers.

2. This might suggest a high weight on environmental considerations in a new agricultural trade negotiation, but agricultural trade arrangements are typically far from being the best instrument to internalize the externalities at issue.

3. The effects of many individual externalities are subtle, and it is often not clear whether freer trade helps alleviate them, or intensifies them.

4. There is a concern for developing countries of agricultural trade barriers against their exports being maintained on environmental grounds.

5. An agricultural trade negotiation would almost certainly be unable to deal centrally with many of the key concerns and issues raised in the wider trade and environment debate; such as multilateral environmental agreements and trade measures, and the rights of countries to use trade restricting measures on environmental grounds. This may be a 
source of comfort for developing countries opposed to a wider negotiation.

6. For all these reasons, I see an agricultural negotiation as likely remaining primarily an agricultural negotiation, with limited environmental content. This could prove to be a source of some frustration for environmental NGO's, especially if a wider trade and environment negotiation receives lower profile than they would seek.

7. The main implication I see for developing countries is that while studies suggest a need for them to substantially raise the profile of their own environmental policy efforts, they should do this through their own domestic policy actions, and not rely on an agricultural negotiation in the WTO as a way of helping significantly remedy their environmental problems. 


\section{REFERENCES}

Abrego, L., C. Perroni, J. Whalley, and R. Wigle (forthcoming) "Trade and Environment: Bargained Outcomes From Linked Negotiations" Review of International Economics (to appear) and NBER Working Paper, no. 6216.

ADB (Asian Development Bank) (1997) Emerging Asia-Changes and Challenges, Manilla.

Agarwal, Anil (1996) "Pay-offs to Progress", Down to Earth (Centre for Science and Environment, New Delhi) 5(10): 31-39.

Anderson, K. (1992a) "Effects on the Environment and Welfare of Liberalization of World Trade: The Case of Coal and Food" in (ed.) K.A. Anderson and R. Blackhurst The Greening of World Trade, London, Harvester-Wheatsheaf.

Anderson, K. (1992b) "Agricultural Trade Liberalization and the Environment: A Global Perspective" The World Economy, vol.15, no.1, pp.153-72.

Barbier, F. (1996) "The Economics of Soil Erosion: Theory, Methodology and Examples" Economy and Environmental Programme of South East Asia, Special Paper, May 1996.

Coase, R. (1960) “The Problem of Social Cost” The Journal of Law Economics.

Cruz, W., H.A. Francisco and Z.T. Conway (1988) "The On-Site and Downstream Costs of Soil Erosion in the Magat and Pantabangan Watersheds" Journal of Philippine Development, vol.15 (26,1), pp.85-111.

Cruz, W., M. Munasinghe and J. J. Warford (1997) “The Greening of Economic Policy Reform' vol.1: Principles; vol.2: Case Studies”, The World Bank Environmental Department and Economic Development Institute.

Ed. Glover D., and T. Jessup (1999) Indonesia's Fires and Haze: The Cost of Catastrophe, IDRC/ISEAS, Singapore and Canada.

Francois, J.F., H. McDonald, and H. Nordström (1996) “The Uruguay Round: a numerically based qualitative assessment" in ed. W. Martin and A. Winters, The Uruguay Round and The Developing Countries, Cambridge University Press, Cambridge.

Goldin, I. and D. van der Mensbrugghe (1996) "Assessing agricultural tariffication under the Uruguay Round " in (eds) W. Martin and L.A. Winters, The Uruguay Round and the Developing Countries, Cambridge University Press.

Harrison, G.W., T.F. Rutherford and D.G. Tarr (1996) "Quantifying the Uruguay Round" in (eds) W. Martin and L.A. Winters, The Uruguay Round and the Developing Countries, Cambridge University Press 1996.

Hathaway, D.E. (1987) "Agriculture and the GATT: Rewriting the Rules", Institute for International Economics, vol. 20, September, Washington D.C.

ICTSD (1999) Bridges Between Trade and Sustainable Development, International Center for 
Trade and Sustainable Development, Geneva, vol.3, no.5, 1999.

Ingersent, K.A., A.J. Rayner, and R.C. Hine (1995). "Expost Evaluation of the Uruguay Round Agricultural Agreement". The World Economy, September, pp.707-728.

Jackson, J.H. (1989) The World Trading System, Cambridge, MA, MIT Press.

Jha, R., and J. Whalley (1999) “The Environmental Regime in Developing Countries” paper presented at a FEEM /NBER Conference, Milan, June 1999.

Knut et.al. (1996) "The Cost of Soil Erosion in Nicaragua” Ecological Economics, vol. 16, pp.129-145.

Lipsey, R.G. and K.J.Lancaster (1957) "The General Theory of the Second Best" Review of Economic Studies, vol.24, pp.11-32.

López, R. (1997) "Evaluating Economywide Policies in the Presence of Agricultural Environmental Externalities: The Case of Ghana" in The Greening of Economic Policy Reform Volume II: Case Studies, W. Cruz, M. Munasinghe and J.J. Warford (eds.), pp. 27-54.

Magrath, W. and P. Arens (1989) "The Costs of Soil Erosion on Java: A Natural Resource Accounting Approach", Environment Working Paper 18, World Bank, Environment Department, Washington, D.C.

Meade, J.E. (1952)"External economies and diseconomies in a competitive situation" Economic Journal, vol.62, March.

Pigou, A.C. (1918) The Economics of Welfare, MacMillan

Resosudarmo, B. (1999) “The Economy Wide Impacts of Integrated Pest Management in Indonesia" Economy and Environment Programme of South East Asia (EEPSEA), Singapore.

Smil, V. (1992) "Environmental Changes as a Source of Conflict and Economic Losses in China" Paper prepared for a Workshop on Environmental Change, Economic Decline, and Civil Strife, Institute for Strategic and International Studies, Kuala Lumpur, 1991.

Swinback, A. (1999) "EU Agriculture, Agenda 2000 and the WTO Commitments" The World Economy, January, vol.22, no.1, pp.41-54.

Tangerman, S. (1997) “A Developed Country Perspective of the Agenda for the Next WTO Round of Agricultural Negotiations" Program for the Study of International Organizations, Occasional Paper, WTO Series no. 5, Geneva.

Tussie, D. (1999) "The Environment and Trade Negotiations: Open Coops in the Developing World" The World Economy, June, vol.22, no.4, pp.535-546.

Uimonen, P., and J. Whalley (1997) Environmental Issues in the New World Trading System, MacMillan, London. 
Uimonen, P. (1998) "The Environmental Dilemmas of the World Trade Organization" in ed. J.J.Schott, Launching New Global Trade Talks: An Action Agenda, Institute for International Economics, Washington, D.C.

UN (1999)Human Development Report, United Nations, New York.

Weerahewa, J. et.al. (1999) "Impact of Trade Liberalization on the Environment: The Case of Tariff Reduction for Potato in Sri Lanka" Economy and Environment Programme of South East Asia (EEPSEA), Singapore.

Whalley, J. (1996) “Trade and Environment Beyond Singapore” NBER Working Paper no. 5768, September.

WTO (1998a) Sanitary and Phytosanitary Measures, WTO Agreement Series, no. 4, Geneva.

WTO (1998b) Annual Report 1998; Geneva.

WTO (1998c) "Non Trade Concerns in the Next Agricultural Negotiations" Submission by Argentina to the Committee on Trade and Environment; WT/CTE/W/97.

WTO (1999a) "Environmental Effects of Trade Liberalization in the Agricultural Sector" Submission by Norway to the Committee on Trade and Environment; WT/CTE/W/100.

WTO (1999b) "Agriculture and the Environment: The Case of Export Subsidies" Submission by Argentina, Australia, Brazil, Canada, Chile, Colombia, Indonesia, Malaysia, New Zealand, Paraguay, the Philippines, Thailand, United States, and Uruguay to the Committee on Trade and Environment; WT/CTE/W/106. 